\title{
Monitorowanie temperatury łożyska nośnego pionowego hydrozespołu
}

\author{
Thrust bearing temperature monitoring \\ of a vertical hydro-set
}

\section{Streszczenie}

Opisano przypadek poważnego uszkodzenia łożyska nośnego pionowego hydro-generatora dużej mocy. Dokonano analizy stosowanego systemu monitorowania i zabezpieczeń dla łożysk oporowych, opisano przyczyny zbyt wolnego zadziałania systemu zabezpieczeń oraz sformułowano wytyczne dla bardziej efektywnego systemu zabezpieczeń.

Słowa kluczowe: łożysko oporowe; monitorowanie i zabezpieczenia; temperatury; położenie; drgania

\begin{abstract}
A serious thrust bearing failure of a high power vertical hydro-generator is described. Analysis of the applied monitoring and protection system for the thrust bearings is provided. Slow response time of the protection system is investigated. A guideline for the more efficient protection system is provided
\end{abstract}

Keywords: thrust bearing, monitoring and protection; temperatures; axial position; vibrations

\section{Wstęp}

W pionowych hydrozespołach łożysko nośne przenosi ciężar wirników i dodatkowo napór wody na wirnik. Zróżnicowanie konstrukcyjne tego łożyska może wynikać ze sposobu smarowania, podparcia segmentów, rodzaju materiału pokrywającego segmenty, etc. Pokrycie może być tradycyjne (babbit) lub polimerowe (np. fluoroplastic, PEEK). Stosowane coraz częściej polimery mogą pracować z temperaturami do $120^{\circ} \mathrm{C}$ wyższymi niż białe metale.

Nośność łożyska jest limitowana przez: (i) minimalną warstwę oleju, (ii) ograniczenia mechaniczne, (iii) maksymalnie dopuszczalną temperaturę powierzchni roboczej łożyska [1]. Ograniczeniem krytycznym maszyn wolnoobrotowych z segmentami babbitowymi jest grubość warstwy oleju. Łożyska polimerowe w warunkach nominalnych obrotów wirnika są limitowane przez temperaturę powierzchni roboczej.

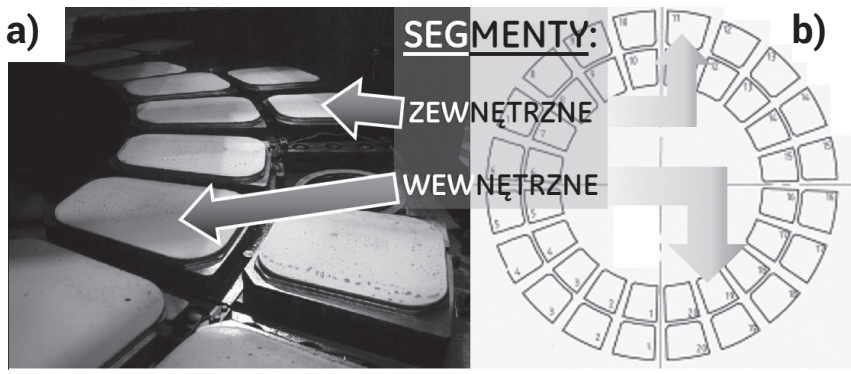

Rys. 1. a) Przykład łożyska oporowego z podwójnymi segmentami na promieniu, b) rozkład segmentów dla omawianego przypadku Fig. 1. a) An example of thrust bearing pads placed in two circles, b) a configuration of segments for the discussed case
Sposób smarowania łożysk nośnych nie zmienił się znacząco od czasu kiedy zaczęto je stosować. Typowo wykorzystywana jest wanna z olejem, w którym są zanurzone segmenty. Problem pojawia się przy zwiększaniu prędkości obrotowej wirnika bowiem po przekroczeniu pewnej średniej prędkości liniowej współpracujących powierzchni ( $50 \mathrm{~m} / \mathrm{s})$ pojawiają się turbulencje oleju zwiększające opory ruchu. Wtedy sensownym jest stosowanie smarowania bezpośredniego, co obniża opory ruchu nawet do $50 \%$. W konsekwencji zmniejsza się temperatura łożyska i zapotrzebowanie na przepływ oleju [2]. Jeśli system chłodzenia nie jest wystarczająco efektywny to materiał łożyskowy zaczyna się topić co prowadzi do znaczących strat bezpośrednich (naprawy maszyny) oraz produkcyjnych.

Opisano nieudane uruchomienie dużego hydrozespołu, dokonano analizy przyczyn wątpliwego działania systemu zabezpieczeń, wskazano na błędy w implementacji czujników oraz sformułowano zalecenia prowadzące do polepszenia działania systemu nadzoru.

\section{Monitorowanie łożysk oporowych}

Dla nadzoru stanu technicznego łożysk stosuje się przede wszystkim czujniki: temperatury, położenia, ciśnienia, poziomu oleju w wannie oraz czasami także jego jakości. Redukcja warstwy oleju między segmentami, a tarczą oporową prowadzi do uszkodzenia segmentu i/lub tarczy

Dr inż. Ryszard Nowicki; mgr inż. Nikolay Morozov - GE Digital, Oddział BENTLY NEVADA.

Autor korespondencyjny/Corresponding author. ryszard.nowicki@ge.com 
oporowej. Liczba czujników temperatury jest uzależniona od liczby segmentów, oraz od obciążenia łożyska [3]. Czujniki wiroprądowe służą do monitorowania położenia osiowego wirnika, dynamiki jego ruchu oraz do monitorowanie grubości warstwy filmu olejowego [1,4]. W/w czujniki winny być podłączone do systemu nadzoru stanu technicznego klasy On-Line.

Wiele pozycji literaturowych omawia pomiary temperatury segmentów łożysk. Mają one jednak na celu głównie porównanie strat $w$ łożyskach babbitowych i polimerowych (przegląd stosowanych technik i wyników opisano w [5]). Pomiary realizowane są głównie na stanowiskach testowych. Cechują się one długą stałą czasową. Ewentualne uszkodzenie łożyska nie niesie ryzyka strat produkcyjnych. Tak więc to co jest wystarczająco dobrą formą monitorowania dla stanowisk testowych nie musi być równie dobre dla rzeczywistej maszyny bowiem zmiana stanu technicznego może mieć także charakter nagły. System monitorowania i zabezpieczeń stanu technicznego winien być projektowany z dobrym rozeznaniem potencjalnych uszkodzeń i prawdopodobieństwa ich wystąpienia, a także cechować się poprawnie dobranymi stałymi czasowymi zabezpieczeń.

Rysunek 2a pokazuje często praktykowany sposób instalacji czujnika temperatury w segmencie łożyska oporowego a rysunek b i rysunek c bardziej poprawne rozwiązanie jego lokalizacji.
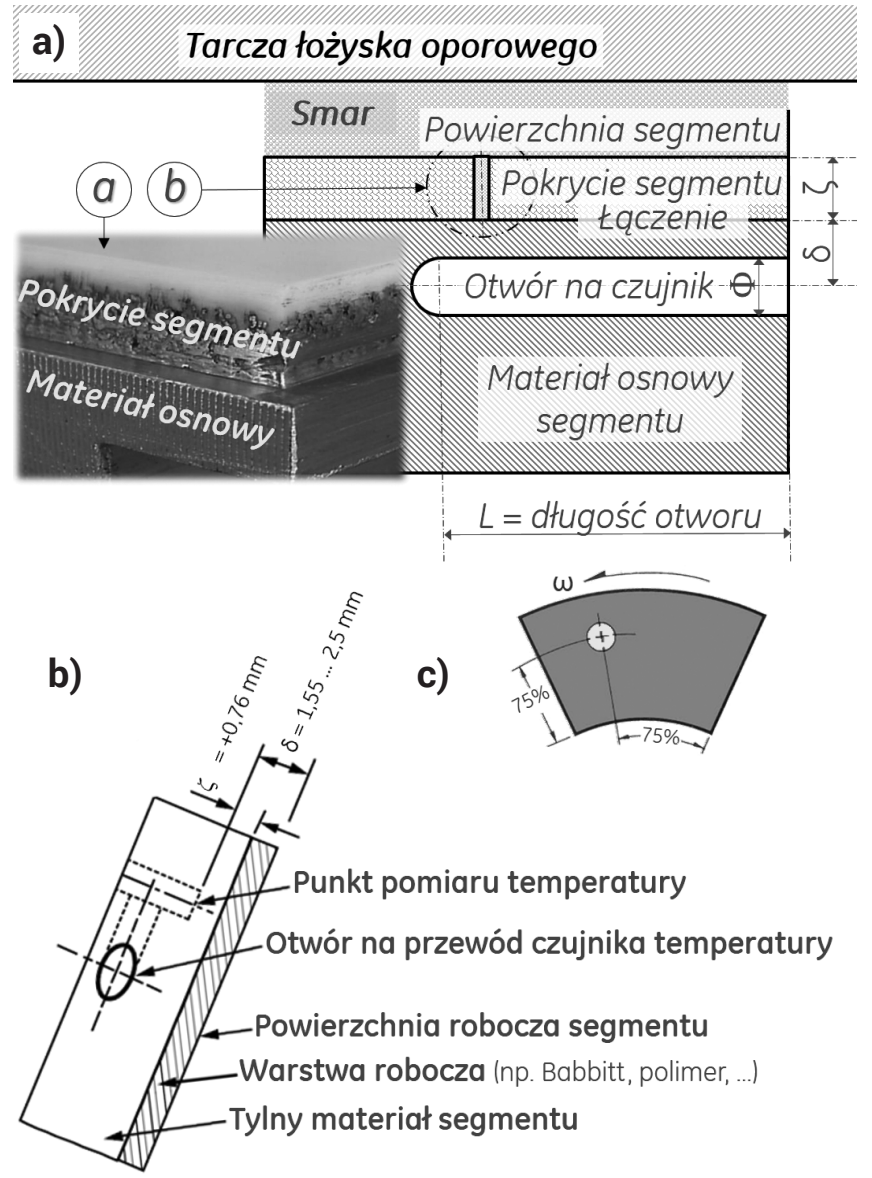

Rys. 2. Pomiar temperatury segmentu: typowy a) oraz zalecany: na grubości b) i kątowo c)

Fig. 2. Bearing pad temperature measurements: a) typical and advised: according to working surface $b$ ), and angular $c$ )

\section{Predykcyjne utrzymanie ruchu wymaga stosowania systemu diagnostyki}

Różne strategie utrzymania ruchu wymagają stosowania systemu nadzoru stanu technicznego posiadającego różne właściwości [6]. Elektrownia w której prowadzono proces uruchomienia nowego hydrozespołu prowadzi utrzymanie ruchu bazujące na stanie technicznym. Wykorzystywany jest profesjonalny system monitorowania i zabezpieczeń SYSTEM 3500 do którego są podłączone głównie czujniki drgań (bezkontaktowe do pomiarów drgań i położeń wirnika oraz sejsmiczne do nadzoru drgań strukturalnych). Dla nadzoru stanu technicznego prowadzi się także monitorowanie temperatur wszystkich łożysk. System monitorowania i zabezpieczeń jest podłączony do serwera systemu akwizycji danych diagnostycznych SYSTEM 1, który dodatkowo importuje (i) pomiary wykorzystywane dla oceny stanu technicznego realizowane przez inne systemy nadzoru, (ii) zmienne procesowe oraz (iii) zmienne środowiskowe gromadzone przez DCS.

\section{Co się wydarzyło}

W czasie kolejnego ruchu testowego nastąpiło odstawienie awaryjne, zainicjowane sygnałem z pomiarów temperatury segmentów wewnętrznych łożyska z pokryciem fluoroplastikowym; czujniki zainstalowane tak jak pokazano na rysunku 2a. Często dla łożysk stosuje się: $L=\sim 170 \mathrm{~mm}$, $\delta=\sim 22 \mathrm{~mm}, \Phi=\sim 25 \mathrm{~mm}, \zeta=\sim 10 \mathrm{~mm}$. Szczegół "a" przedstawia widok fragmentu segmentu od strony jego narożnika. Oczekiwana warstwa filmu wynosi ho $=\sim 25 \mu \mathrm{m}[7]$.
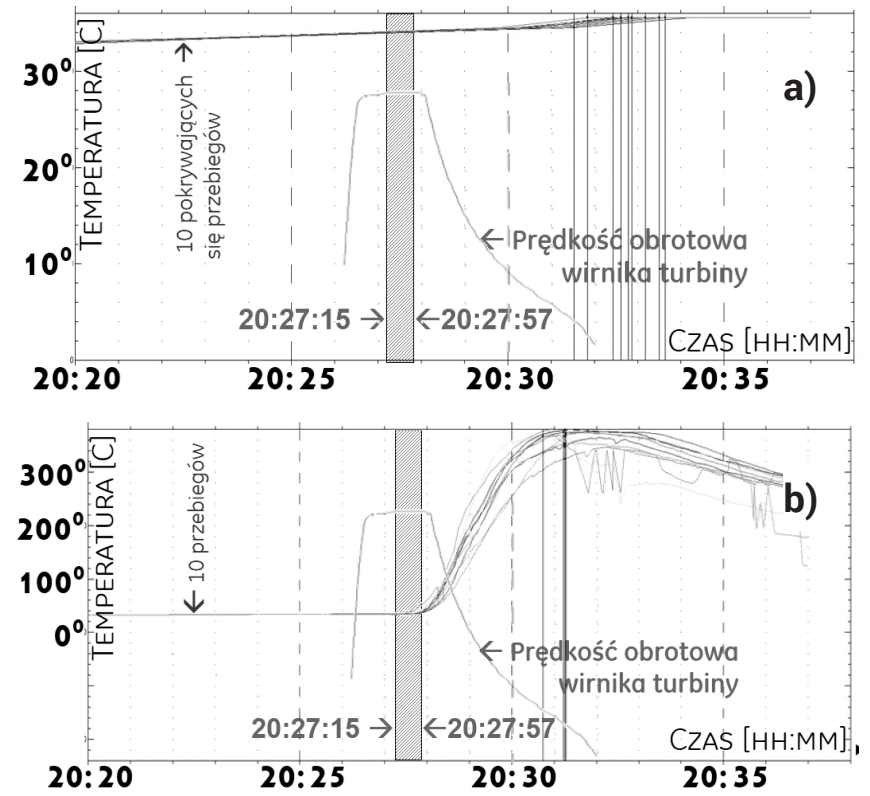

Rys. 3. Zmiany temperatury 10 segementów a) zewnętrznych i b) wewnętrznych

Fig. 3. Temperature changes of 10 bearing pads from a) outer circle and b) internal circle

Rysunek 3 pokazuje zmianę temperatur w czasie dla 10 segmentów zewnętrznych (A) i 10 wewnętrznych (B) na tle krzywej prędkości wirnika, a obszar czerwony informuje o jego prędkości nominalnej. W czasie uruchomienia stwierdzono także nieznaczny wzrost poziomu oleju. $\mathrm{Na}$ rysunku a) widoczny jest wolny wzrost temperatur segmentów zewnętrznych aż do osiągnięcia stabilizacji nagrzania dla temperatury $\sim 35,50 \mathrm{C}$. Dla segmentów wewnętrznych, maksymalne wartości zarejestrowanych temperatur wynosiły $340 . . .3800 \mathrm{C}$. Temperatury te zaczęły się zmniejszać $\sim 5$ minut po rozpoczęciu odstawienia hydrozespołu z gradientem $\sim-200 \mathrm{C} / \mathrm{min}$.

W rzeczywistości temperatury segmentów zewnętrznych musiały być wyższe od zarejestrowanych. W [8] 
można znaleźć informację że $\zeta=1.5 \mathrm{~mm}$ warstwa PTFE łożyska powoduje zmniejszenie temperatury o $23{ }^{\circ} \mathrm{C}$ co oznacza, że przy dużym łożysku, posiadającym pokrycie robocze o grubości $\zeta=\sim 10 \mathrm{~mm}$, zmiana temperatury między powierzchnią roboczą, a łączeniem będzie najprawdopodobniej kilka razy większa. Czujniki TC (termopary) wykorzystywany $\mathrm{w}$ [8], był zlokalizowany $\delta=4 \mathrm{~mm}$ poniżej warstwy polimeru, natomiast dla typowego segmentu dużego łożyska $\delta>20 \mathrm{~mm}$. Nawet w przypadku łożyska babbitowego mamy do czynienia ze znaczącą różnicą temperatury między powierzchnią roboczą, a odczuwaną przez czujnik. W [9] podano, że dla czujnika TC zainstalowanego $\delta=\sim 3 \mathrm{~mm}$ poniżej warstwy babbitu system monitorowania wskazuje temperaturę o 400C niższą niż występująca na powierzchni roboczej.

Po otwarciu łożyska stwierdzono, że (i) wszystkie segmenty wewnętrzne były zniszczone $\mathrm{w}$ wyniku przegrzania oraz, że (ii) wszystkie segment zewnętrzne znajdowały się w dobrym stanie technicznym. Powierzchnia robocza tarczy łożyska nośnego wymagała obróbki mechanicznej. Przebadany olej nie wskazywał na odchylenie jego składu chemicznego do normy.

\section{Wymagania normowe dla nadzoru łożyska oporowego}

Na nadzór łożyska oporowego można spojrzeć przez pryzmat standardów oraz najlepszych praktyk. Zasady nadzoru łożyska oporowego są opisane w [10]. Standard ten, opracowany przez American Petroleum Institute jest adresowany przede wszystkim dla maszyn użytkowanych w tzw. obszarze "oleju i gazu". Został on jednak rozpoznany jako bardzo przydatny i w konsekwencji jest powszechnie akceptowany $w$ wielu innych obszarach. W zakresie wytycznych jakościowych nadzoru temperatury łożysk może on być stosowany prawie bez żadnych ograniczeń dla wielu innych maszyn (vide 6.1.9.2.2 w [10]). Dla łożysk oporowych standard wymaga prowadzenia pomiarów (i) temperatury wybranych segmentów łożyska oraz (ii) położenia osiowego wirnika. Dla monitorowania położenia osiowego wymagane jest stosowanie 2 sond bezkontaktowych pracujących w logice zabezpieczeń “2 z 2". Takie podejście (nazwijmy je SCENARIUSZ l) jest wystarczająco dobre w przypadku agregatów mających łożyska oporowe zlokalizowane na końcach linii wałów oraz dla czujników położenia instalowanych z zewnątrz, tzn. ma miejsce ciągły dostęp do czujników, a w przypadku konieczności wymiany któregoś $z$ nich można ten proces przeprowadzić bez rozbierania węzła łożyskowego maszyny. Natomiast w przypadku maszyn krytycznych, które posiadają łożyska oporowe wewnętrzne ( $z$ punktu widzenia ciągu wirników), lub czujniki umieszczone wewnątrz maszyny (co uniemożliwia szybki do nich dostęp), należy stosować trzy czujniki nadzoru położenia osiowego i logikę zabezpieczeń „2 z 3” («SCENARIUSZ II).

W przypadku hydro-zespołów krytycznych, w zależności od ich konstrukcji oraz od dostępności do tarczy mocowanej do wirnika i umożliwiającej realizację pomiaru winien być stosowany albo SCENARIUSZ I albo II.

Głównym celem monitorowania temperatury łożyska jest obserwacja temperatury warstwy roboczej segmentu lub dokładniej temperatury powierzchni roboczej segmentu. W ogólności można rozpatrywać dwa sposoby mocowania czujnika temperatury w segmencie: czujnik osadzony w warstwie roboczej segmentu lub osadzony w segmencie poza tą warstwą. Oczywiście najlepiej byłoby mieć czujnik osadzony bezpośrednio w warstwie roboczej i to tak blisko powierzchni roboczej jak to tylko możliwe. Bowiem tylko takie osadzenie czujnika gwarantuje minimalną zwłokę czasową między zmianą temperatury tej powierzchni i rozpoznaniem tego faktu przez system monitorowania i zabezpieczeń. Taki wymóg jest szczególnie ważny dla segmentów z pokryciem polimerowym, których przewodność cieplna jest $~ 170$ razy słabsza niż babbitu.

Standard [10] wymaga lokalizacji czujnika temperaturowej $w$ odległości $\zeta=\sim+0,75 \mathrm{~mm}$ poniżej dolnej powierzchni warstwy roboczej (vide rys. 2B). Dla różnych maszyn i dla różnych pokryć odległość $\zeta$ może być różna. Np. są producenci turbin parowych, którzy stosują $\zeta=0 \mathrm{~mm}$, a nawet $\mathrm{w}$ niektórych przypadkach ujemne wartości $\zeta$ jeśli nie wpływa to negatywnie na połączenie materiału roboczego łożyska z tylnym materiałem segmentu. Rysunek 2C charakteryzuje wymaganą lokalizację osi czujnika opisywaną żargonowo jako "75/75". Pod żargonem rozumie się: $75 \%$ długości kątowej segmentu na kierunku obrotów wirnika $\omega$ oraz $75 \%$ długości promieniowej segmentu, na kierunku od jego średnicy wewnętrznej do zewnętrznej. Taki scenariusz jest wystarczająco dobry dla wirników obracających się w jednym kierunku. Dla hydrozespołów odwracalnych (tzn. pracujących także jak elektropompy) niezbędne jest stosowanie w segmencie dwóch czujników zlokalizowanych 75/75 i 25/75 (pierwsza liczba mówi o pozycji kątowej).

Pogorszenie jakości monitorowania temperatury może być spowodowane sposobem mocowania czujnika i wykorzystywanej dodatkowo w tym celu jego obudowy. Podstawowym zadaniem obudowy jest ochrona czujnika przed uszkodzeniem. Jej stosowanie wpływa na wydłużenie stałej czasowej pomiaru i może także wpływać na jego dokładność. Celem uzyskania stałego i dobrego kontaktu z materiałem roboczym łożyska winna być stosowana sprężyna dociskająca. Zapewnia ona kompensowanie rozszerzalności cieplnej i eliminuje wpływ potencjalnej szczeliny, tzn. minimalizuje zmiany przewodności cieplnej i w konsekwencji fluktuacje wartości stałej czasowej.

Świadomość wyżej opisanych problemów powoduje, że pewni producenci maszyn stosują „modyfikacje” mające na celu polepszenie monitorowania temperatury segmentów. Jedną z nich jest dodatkowy otwór (vide rys. $2 A$ - szczegół "b"). Jest on zlokalizowany w warstwie roboczej dokładnie nad znajdującym się w obudowie sensorem temperatury. Jego intencją jest doprowadzenie gorącego oleju bezpośrednio do tylnego materiału segmentu, w którym jest zainstalowany czujnik i w konsekwencji skrócenie stałej czasowej. Inna, bardziej zaawansowana modyfikacja, polega na wykonaniu głębszego otworu, umożliwiającego doprowadzenie oleju bezpośrednio do kieszeni z czujnikiem, oraz wykonanie drugiego prostopadłego otworu umożliwiającego cyrkulację oleju poprzez kieszeń i w konsekwencji dalsze polepszenie (tzn. skrócenie) stałej czasowej pomiaru [11].

Wiele hydrozespołów posiada czujniki temperatury zlokalizowane w znacznej odległości od materiału roboczego łożyska oporowego. Odległość ta jest znacząco większa od zalecanej w [10]. Taka lokalizacja bagnetowego czujnika temperatury $w$ kieszeni jak pokazana na rysunku 2 skutkuje w zwiększeniu opóźnienia czasowego od wzrostu temperatury na powierzchni roboczej segmentu do rozpoznania tego faktu przez system monitorowania i zabezpieczeń. Dodatkowo wzrost odległości " $\delta$ " potęguje to opóźnienie. Na rysunku 4 pokazano typowy sposób 
zabudowy czujnika temperatury w segmentach. Pokazany czujnik (wraz z jego obudową) nie posiada sprężyny dociskowej. Z tego względu nie jest w stanie zapewnić w dłuższym czasie takiego samego kontaktu z powierzchnią otworu dla poszczególnych segmentów. Możliwe zróżnicowanie kontaktu czujników w kieszeniach kolejnych segmentów łożyska wpływa na zwiększenie rozrzutu pomiarów dla segmentów pozostających w warunkach takiego samego obciążenia.
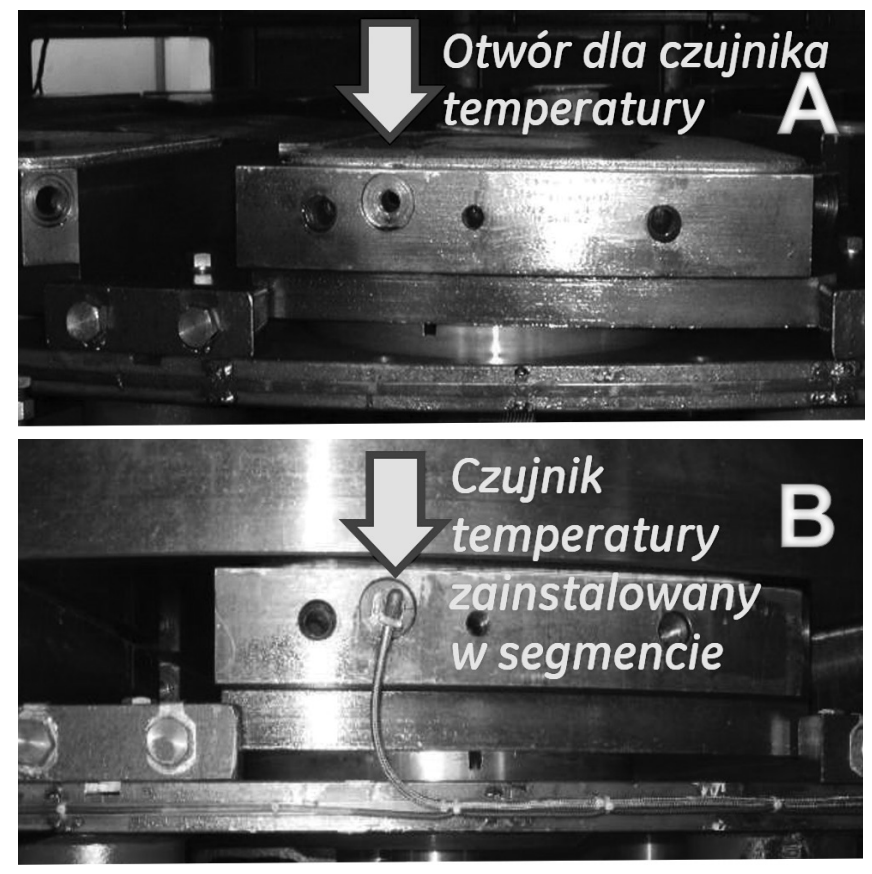

Rys. 4. Monitorowanie temperatury segmentu: a) widok przed instalacją czujnika i b) po

Fig. 4. A pad temperature monitoring: a) a view before transducer fixing, and b) after

\section{Pomiary stowarzyszone dla omawianego przypadku}
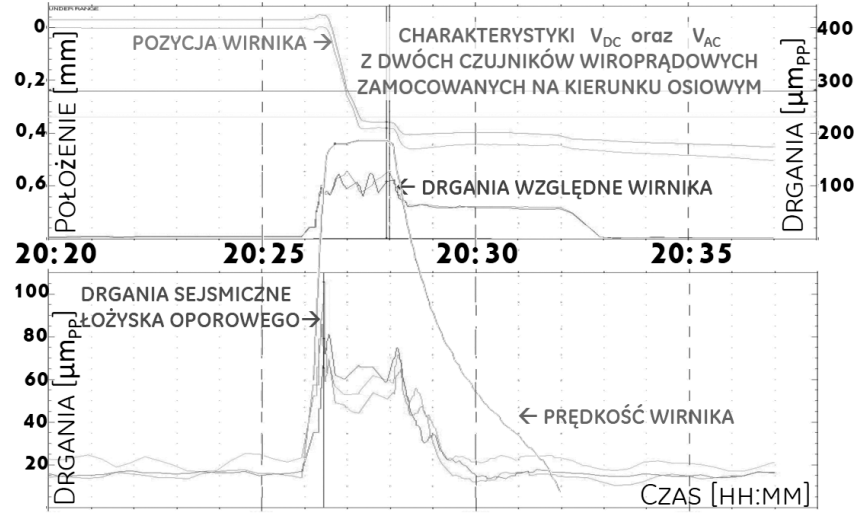

Rys. 5. Przebiegi wybranych sygnałów drgań w czasie problematycznego rozruchu

Fig. 5. Trends of selected vibration signals during the problematic startup

Rysunek 5 przedstawia przebiegi drgań dwóch czujników bezkontaktowych oraz trzech czujników sejsmicznych dla okna czasowego identycznego jak zastosowane dla wykresów na rysunku 3.

Czujniki były utwierdzone do wanny i zorientowane równolegle do osi hydro-zespołu. Generują one sygnały Vac informujące o drganiach oraz Vdc informujące o osiowej zmianie położenia wirnika (lepiej: informują o zmianie położenia osiowego tego fragment wirnika, który jest obserwowany przez czujniki). Obydwa pomiary są realizowane w odniesieniu do punktu mocowania czujników. Czujniki akcelerometryczne były zorientowane pionowo i mocowane do obu łożysk prowadzących oraz do konstrukcji wsporczej łożyska nośnego. Sygnały z wszystkich

Tablica I. Zdarzenia i fakty z uruchomienia maszyny prowadzącego do awarii

Table I. Events and facts from the machine startup resulting in failure

\begin{tabular}{|c|c|c|c|c|c|}
\hline \multicolumn{3}{|c|}{ Zdarzenia i fakty } & \multirow{2}{*}{$\begin{array}{c}\text { Czas: } \\
\text { [hh:mm:ss] }\end{array}$} & \multirow{2}{*}{$\begin{array}{c}\begin{array}{c}\text { Czas naliczany od } \\
\text { początku rozruch [s] }\end{array} \\
0\end{array}$} & \multirow{2}{*}{$\begin{array}{c}\text { Liczba obrotów } \\
\text { wirnika od początku } \\
\text { rozruch [-] }\end{array}$} \\
\hline Prędkość zerowa & l & Start hydrozespołu & & & \\
\hline $05 \% \chi\left(^{*}\right)$ dla ax & & $(0,1 \mathrm{~mm})$ & $20: 26: 48$ & 48 & 35 \\
\hline $10 \% x$ dla ax & & $(0,2 \mathrm{~mm})$ & $20: 26: 56$ & 56 & 77 \\
\hline $15 \% x$ dla ax & & $(0,3 \mathrm{~mm})$ & $20: 27: 11$ & 71 & 131 \\
\hline Obroty nominalne & & & $20: 27: 15$ & 75 & 140 \\
\hline $\begin{array}{l}\text { Odstawienie awaryjne z } \\
\text { wewnętrznych }\end{array}$ & & eratury segmentów & $20: 27: 57$ & 117 & 238 \\
\hline $20 \% x$ dla ax & & & $20: 28: 15$ & 135 & 279 \\
\hline $\begin{array}{l}\text { Monitorowanie temperat } \\
\text { malnych temperatur dop } \\
\text { z pokryciem PTFE }\left(260^{\circ}\right.\end{array}$ & 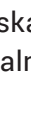 & $\begin{array}{l}\text { na osiągnięcie maksy- } \\
\text { acy ciągłej łożysk }\end{array}$ & $20: 29: 30 \pm 30[s]$ & $210 \pm 30$ & 385 \\
\hline $\begin{array}{l}\text { Monitorowanie temperat } \\
\text { temperaturę upłynnienia }\end{array}$ & & że segmenty osiągnęły & $20: 30: 25 \pm 55[s]$ & $265 \pm 55$ & 431 \\
\hline ZATRZYMANIE WIRNIKA & & $\mathrm{O} Ł U$ & $20: 33: 00$ & 420 & 480 \\
\hline
\end{tabular}


w/w czujników podłączono do SYSTEM 3500, a w systemie diagnostyki były obrazowane $\mathrm{w}$ dziedzinie przemieszczeń drgań.

Analiza krzywych na rysunku 5 przedstawia przebiegi drgań dwóch czujników bezkontaktowych oraz trzech czujników sejsmicznych dla okna czasowego identycznego jak zastosowane dla wykresów na rysunku 3.

Analiza rysunku 5 prowadzi do następujących wniosków:

I. Drgania względne nie występują kiedy wirnik się nie obraca.

II. Nieprzerwanie obserwowane są drgania z czujników sejsmicznych, do czego przyczyniają się także źródła zlokalizowane poza hydrozespołem ( $\longleftarrow$ szum tła); poziom szumu: $20 \mu \mathrm{mP}-\mathrm{P}$.

III. Wszystkie poziomy drgań wzrastają kiedy wirnik zaczyna się obracać.

IV. Drgania sejsmiczne osiągają wartości maksymalne w chwili poprzedzającej osiągnięcie obrotów nominalnych oraz wkrótce po rozpoczęciu odstawienia hydrozespołu; dla obrotów nominalnych poziomy drgań wynoszą $60 \pm 10 \mu \mathrm{mP}-\mathrm{P}$.

V. Drgania osiowe wirnika są prawie dwukrotnie wyższe od drgań sejsmicznych; dla prędkości roboczej wy-

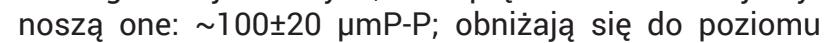
$\sim 60 \mu \mathrm{mP}-\mathrm{P}$ po rozpoczęciu odstawienia, gdy prędkość wirnika jest poniżej 100 RPM i stabilizują się po $210 \mathrm{~s}$ (wtedy obroty wynoszą 8 RPM); po kolejnej minucie drgania te zanikają.

VI.W okresie poprzedzającym rozruch pozycja osiowa wirnika jest stała; w czasie ruchu wirnik systematycznie przemieszcza się do dołu; całkowita zmiana położenia wynosi -0,45 mm; zaobserwowana zmiana może być spowodowana przez: (i) zużycie łożyska oporowego, (ii) zmianę grubości filmu olejowego, (iii) spowodowaną tarciem lokalną deformację termiczną tarczy łożyska oporowego, (iv) deformację miejsca do którego przymocowane są czujniki.

Dla opisywanego przypadku zmiana położenia osiowego wirnika ax była monitorowana z pomocą dwóch czujników, natomiast ze względu na fakt ich usytuowania wewnątrz wanny bardziej poprawnym byłoby zastosowanie SCENARIUSZA II. Poważnym błędem był także brak włączenia pomiaru ax do systemu zabezpieczeń.

Żywotność łożysk polimerowych jest szacowana na 40 do 70 lat. W Elektrowni Ust-Ilim po 20 latach pracy takich łożysk zużycie powierzchni roboczej wyniosło $\sim 0,3 \mathrm{~mm}$, a niektóre łożyska oporowe hydrozespołów dużej mocy stosują segmenty posiadające pokrycie dopuszczające nawet do 1,5 mm zużycia. Natomiast dla opisywanej tu awarii, tylko $\mathrm{w}$ trakcie jednego rozruchu, zarejestrowano ax wynoszącą prawie $0,5 \mathrm{~mm}$.

W tablicy zaprezentowano wybrane fakty $\mathrm{z}$ historii opisywanego przypadku etykietowane czasem oraz liczbą obrotów od początku uruchomienia. Odstawienie hydrozespołu bazujące na zabezpieczeniu temperaturowym zadziałało po 238 obrotach wirnika. Włączając pomiar ax do systemu zabezpieczeń oraz ustawiając alarm na przemieszczenie wirnika wynoszące 0,1 mm można było rozpoznać nienormalną sytuację i odstawić maszynę już po 35 obrotach wirnika.

\section{Podsumowanie}

Dla opisanego przypadku awarii właściciel hydrozespołu był bardzo zawiedziony, że system monitorowania drgań, które były włączone do systemu zabezpieczeń, nie pokazał żadnej zmiany pomiarów. Natomiast jest to dobrze znany fakt, że w przypadku nie każdego uszkodzenia maszyny drgania są wystarczająco dobrym symptomem zmiany stanu technicznego. Taka sytuacja dotyczy m.in. niektórych form przycierania. W szczególności wtedy, kiedy współczynnik tarcia między trącymi powierzchniami jest bardzo mały, a nacisk duży i obwodowo symetryczny. W takich sytuacjach generowana jest lokalnie znaczna ilość ciepła, która (do czasu) nie ma większego wpływu na charakterystyki drgań.

Dla uruchomienia zakończonego awarią producent maszyny znalazł różnicę w skonfigurowaniu DCS, w stosunku do wcześniejszych rozruchów: natrysk zimnego oleju na tarczę łożyska oporowego został włączony jeszcze przed podaniem wody na turbinę. Zdaniem producenta spowodowało to powstanie podciśnienia w rejonie segmentów zewnętrznych, co wtórnie przyczyniło się do podniesienia poziomu oleju w tym rejonie wanny i obniżało poziom oleju w rejonie bardziej centralnym gdzie znajdowały się segmenty wewnętrzne.

Różne cechy systemu monitorowania i zabezpieczeń wpływają na jakość jego działania. Mogą to być np. możliwości autodiagnostyki systemu (podłączonych do systemu czujników i współpracujących z nimi kanałów elektroniki) lub możliwości w zakresie lepszego zarządzania alarmami [12,13]. Niestety, żaden system monitorowania nie jest w stanie rozpoznać i skorygować niepoprawnie (a nawet błędnie) dobranych i/lub podłączonych czujników, a tym bardziej skorygować wynikających z tego faktu błędów. Wciąż jeszcze znaczna liczba maszyn wirnikowych (zarówno z pozioma jak i pionową osią wirnika) posiada czujniki temperatury podłączone niezgodnie z zasadami najlepszej praktyki i z tego powodu jakość działania systemu monitorowania nie jest tak dobra jak mogłaby być. Kilka typowych przykładów błędnych instalacji czujników temperatury pokazano w [14] natomiast tutaj opisano przykład nieprawidłowego wdrożenia monitorowanie temperatury segmentów łożyska nośnego agregatu o dużej mocy oraz sformułowano wytyczne prowadzące do polepszenia jakości jego monitorowania:

I. Nie powinno być stosowane rozwiązanie wykorzystujące umieszczony poziomo w segmencie czujnik temperatury ze względu na duże opóźnienie czasowe między zmianą temperatury powierzchni roboczej, a reakcją systemu monitorowania na tę zmianę.

II. Czujniki bagnetowe stosowane w przeszłości dla łożysk babbitowych są automatycznie wykorzystywane po modernizacji tych łożyska na łożyska polimerowe. Taka modernizacja zwiększa opóźnienie czasowe w rozpoznawaniu zmian temperatury warstwy roboczej, bowiem przewodność cieplna polimerów jest znacznie niższa 
niż babbitu. Takie monitorowanie temperatury jest wciąż akceptowalne dla rozpoznawania powolnych zmian stanu technicznego segmentów jednak nie jest wystarczające dla szybkiego rozpoznania pracy łożyska z wadliwym smarowaniem.

III. Czujnik temperatury winien być w najgorszym przypadku zlokalizowany w podstawie segmentu ale możliwie blisko warstwy roboczej łożyska; jego bezpośrednie usytuowanie w warstwie roboczej minimalizuje zwłokę czasową i daje wyniki monitorowania temperatury bardziej odpowiadające rzeczywistości; w konsekwencji maszyna jest lepiej zabezpieczona na okoliczność szybko rozwijających się problemów.

IV. Staranna instalacja dobrej jakości czujników temperatury w segmentach rzutuje na mniejszy rozrzut wyników pomiarów prowadzonych w podobnych warunkach oraz minimalizuje zmianę czułości czujników w kolejnych latach wykorzystywania systemu monitorowania. Dla pomiaru temperatury w łożyskach ślizgowych winny być wykorzystywane czujniki ze sprężynami zapewniającymi ciągły i podobny docisk do podlegającej pomiarowi powierzchni. Czujniki bez sprężyn są dobre dla pomiarów informacyjnych ogólnego przeznaczenia, w przypadku których nie występują szybkie zmiany temperatury pociągające za sobą zagrożenie dla majątku (i/lub procesu). Bardziej wiarygodne monitorowanie temperatury umożliwia bardziej odpowiedzialne zarządzanie stanem technicznym nadzorowanego majątku produkcyjnego.

V. Różne metody monitorowanie oleju są ważne dla nadzoru stanu technicznego majątku produkcyjnego. Dla łożysk oporowych jest jednak błędem ograniczanie się do zabezpieczenia na okoliczność wzrostu temperatury oleju. W przypadku zerwania filmu olejowego dochodzi do szybkiego zużycia powierzchni roboczej łożyska i w konsekwencji do zmiany położenia osiowego (tu: pionowego) wirnika. Zmiana grubości filmu może być łatwo rozpoznana z pomocą bezkontaktowych czujników wiroprądowych zainstalowanych w wannie łożyska; pomiar taki bezwzględnie winien być włączony do systemu monitorowania i zabezpieczeń. Zróżnicowanie pomiarów w systemie nadzoru stanu technicznego prowadzi na ogół do bardziej poprawnych wniosków co do zmiany stanu hydrozespołu.

VI. Wymagana liczba czujników temperatury dla pojedynczego łożyska jest uzależniona od liczby segmentów oraz może być uzależniona od ich obciążenia i charakteru pracy hydrozespołu.

VII. Wymagana liczba czujników temperatury dla pojedynczego segmentu (jeśli są instalowane) jest uzależniona od liczby kierunków obrotów roboczych hydrozespołu (1 lub 2).

VIII. Od wielu lat do nadzoru stanu technicznego w [10] wymaga się wykorzystywania zintegrowanych systemów nadzoru; tzn. takich systemów, w których wszystkie pomiary realizowane dla nadzoru (drgania, pozycje, temperatury, ...) są podłączone do jednego systemu monitorowania. Wymóg ten winien być szczególnie przestrzegany w przypadku stosowania utrzymania ruchu bazującego na stanie technicznym.

\section{Literatura}

[1] A.J. Leopard: Tilting Pad Bearings - Limits of Operation, Lubr. Eng Vol 32, s. 637-644, 1975.

[2] H.P. Bloch: Practical Lubrication for Industrial Facilities, 2nd Ed., Fairmont Press, ISBN 1420071513, 2009.

[3] A.E. Aleksandrov. Temperature control of thrust bearings with elastic metal-plastic segments, Hydrotechnical Construction, Vol.22(7), s. $395-402,1988$.

[4] R. Nowicki: Thrust Bearing Position Monitoring, ORBIT, Vol. 31(1), s. 52-59, 2011.

[5] J. Zhou: Temperature Monitoring of PEEK Bearings, 71st STLE Annual Meeting and Exhibition, Las Vegas, May 15-19, 2016.

[6] R. Nowicki: Współczesne kierunki rozwoju stacjonarnych systemów wspomagania oceny stanu technicznego majątku produkcyjnego, Materiały $41 \mathrm{KKBN}, \mathrm{s} .253-257,2012$.

[7] S.R. Schmid, B.J. Hamrock, B.O. Jacobson: Fundamentals of Machine Elements, 3rd Ed., Published by CRC Press, 2014.
[8] S.B. Glavatskih: Evaluating thermal performance of a PTFE-faced tilting pad thrust bearing, ASME. J. Tribol. Vol. 125.2, s. 319-324, 2003.

[9] H. Maxwell: How to Install Maintainable Bearing Temperature Sensors, Proceedings of the 10th Turbomachinery Symposium, Texas A\&M Univ., s. 131-139, 1981.

[10] API STD 670, Machinery Protection Systems, 5th Ed., 2014.

[11] S.B. Glavatskih: A method of temperature monitoring in fluid film bearings, Tribology International Vol. 37.2, s.143-148, 2004.

[12] R. Nowicki, M. Snyder. Alarm Management for Hydropower Plants, Power Engineering, s. 124...131, 2015.

[13] R. Nowicki: A way for a better alarm management, Water Power \& Dam Construction, s. 30-32, 2016.

[14] R. Nowicki: Pomiary temperatury łożysk (cz. II): Szczegóły dotyczące poprawności instalacji czujników, Inżynieria i UR Zakładów Przemysłowych, Nr 07-08 s. 64-75, 2016. 